\title{
Influence of adiposity (genetic or hormonal) on the metabolism of amino acids and nutritional responses
}

\author{
B Leclercq ${ }^{1}$, B Sève 2 \\ 1 INRA, Recherches Avicoles, 37380 Nouzilly; \\ 2 INRA, Recherches Porcines, 35590 Saint-Gilles, France
}

\begin{abstract}
Summary - The data published on the modifications of amino-acid metabolism associated with variations of obesity from genetic or hormonal origin have been reviewed. In the first part monogenic models of mice and rats are described. Obesity in humans is analysed in the second part. Lastly, non-ruminant genotypes or hormone-treated ones (chickens and pigs) are reviewed in the third part. Although different mechanisms are probably at the origin of these differences, many similarities can be drawn. Obesity is always associated with: 1) less efficient utilization of dietary amino acid; 2) a high concentration of branched-chain amino acids in plasma; 3 ) a deviation of carbon from amino acid towards gluconeogenis and lipogenesis; and 4) a less pronounced sensitivity to amino-acid imbalance in the diet.
\end{abstract}

amino acid / obesity / genetics / pig / poultry

Résumé - Influence de l'adiposité (génétique ou hormonale) sur le métabolisme des acides aminés et réponses nutritionnelles. Les travaux relatifs aux modifications du métabolisme des acides aminés associées aux variations de degré d'adiposité d'origine génétique ou hormonale ont été revus. Ces résultats concernent soit les modèles monogéniques murins (1re partie), soit les obésités humaines, de l'origine génétique desquelles on n'est pas toujours assuré (2 partie), soit, enfin, les espèces dites de rente, essentiellement porc et poulet ( $3^{e}$ partie). Bien que des mécanismes différents soient probablement à l'origine de ces différences d'engraissement selon les espèces, un certain nombre d'analogies peuvent être constatées. L'adiposité importante est associée à une mauvaise efficacité de l'utilisation métabolique des acides aminés alimentaires, à une élévation des teneurs plasmatiques en acides aminés à chaîne ramifiée, à une déviation d'une partie du carbone des acides aminés vers la néoglucogenèse et la lipogenèse et, enfin, à une moindre sensibilité aux déséquilibres des profils d'acides aminés du régime.

acides aminés / obésité / génétique / porc / poulet 


\section{INTRODUCTION}

Many papers have been published on metabolic and hormonal changes induced by genetic obesity in laboratory animals, farm species and humans. Most deal with glucose and lipid metabolism. Very few experiments have been performed on modifications of amino-acid metabolism due to excessive or reduced adiposity. This paper is intended to review this specific aspect, which may lead to important consequences on the nutrition of these species. Results from different species are presented successively, since observed obesities come likely from different origin.

Much information has been published for obese rodents (rats and mice) which are extensively used in laboratory studies. Since these are monogenic obesities we may assume that understanding the mechanisms involved should be easier than in polygenic obesities. These models are presented in the first part.

Fewer papers have been published on obesities of humans. However, amino-acid metabolism was frequently investigated in these types of obesities, although they were perhaps not always entirely of genetic origin. Moreover they frequently concern adults. This situation is slightly different from studies on growing rodents or growing farm animals, which are considered in the third part of this review.

Geneticists have developed models of leanness in farm animals, mainly pigs and chickens, since low adiposity provides many advantages in animal production: reduced costs of feeding, better carcass quality and many other associated responses.

For pigs there are mixed experiments performed on lines selected for low- or highadiposity and other experiments on the effects of hormonal treatments that modify adiposity.

\section{RODENT MODELS OF OBESITY}

Several studies performed on Zucher rats showed that the obese rat exhibits a lower protein deposition (Radcliffe and Webster 1976; Lobley et al, 1978; Radcliffe and Webster 1978). This difference is associated with a lower protein efficiency. When regression lines between protein gain and protein consumption are calculated for the obese genotype and its normal counterpart, the obese rat needs more protein to insure a protein gain similar to or slightly lower than that of the normal rat (Chu et al, 1978; Radcliffe and Webster, 1978; Clearly and Vasselli, 1981). Similar conclusions were drawn by Lin et al (1977) from their experiments on ob/ob mice.

Some authors also noted that the plasma concentration of several amino acids were significantly different between obese and normal rodents. In most experiments levels of branched-chain amino acids (BCAA) were higher in obese genotypes (table I). Differences are sometimes given for other amino acids such as glucose-forming amino acids. Yamini et al (1991) observed that alanine and arginine are found at lower concentrations in obese $L A / N-c p$ rats.

Total or muscular proteogenesis and proteolysis were measured in several experiments using ${ }^{14} \mathrm{C}$-labelled amino acids (table II). In most experiments proteinogenesis was reduced and proteolysis was frequently higher in obese rodents. This last difference is proposed as the origin of higher levels of $\mathrm{BCAA}$ in plasma.

Other modifications of biochemical reactions were observed (table III). Transport of amino acids in muscles in vitro is impaired (Lemarchand and Freychet 1980), which could account for the reduction of proteogenesis in obese genotype. Liver transaminase activities are enhanced in parallel in the liver (Yamini et al, 1991) delivering more carbon chains which are used for fatty acid 
Table I. Plasma concentration of branched-chain amino acid in obese rodents.

Species

Zucker rat ob/ob mouse ob/ob mouse ob/ob mouse

Zucker rat

LA $/ N$-cp rat
Reference

Kleinknecht et al (1980)

Chee et al (1981a)

Chee et al (1981b)

Tews and Harper (1982)

Jacob et al (1992)

Yamini et al (1991)
Observation

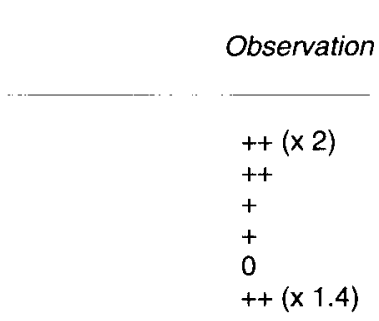

$0=$ no difference $;+=$ obese slightly superior to normal; $++=$ obese largely superior to normal. Between parentheses: the ratio obese/normal.

Table II. Proteogenesis and proteolysis in monogenic models of obesity in rodents.

Reference

Webster et al (1978)

Dunn and Hartsook (1980)

Dumas et al (1982)

Dunn et al (1982)

Sharghill et al (1984)

Chan et al (1985)

Durschlag and Layman (1983)
Species

Zucker rat

Zucker rat

Zucker rat

Zucker rat

ob/ob mouse

Zucker rat

Zucker rat

\section{Proteinogenesis Proteolysis}

$\begin{array}{ll}- & \\ - & + \\ + & + \\ + & + \\ - & \\ - & \end{array}$

$0=$ no difference between obese and normal; $+=$ obese superior to normal $;-=$ obese inferior to normal.

Table III. Biochemical changes induced by obesity in obese rodents.

Reference

Dunn and Hartsook (1980)

Lemarchand and Freychet (1980)

Serra et al(1991)

Yamini et al (1991)

Yamini et al (1991)
Species

Zucker rat

ob/ob mouse

Cafeteria rat

LA/N-cp rat

LANN-cp rat

\section{Observation}

High incorporation of carbon from amino acids into fatty acids

Reduction of amino-acid transport into muscle (in vitro)

Increased synthesis of alanine by intestine, increased synthesis of glutamine by muscles

Increased neoglucogenesis, increase lipogenesis

Increased activities of liver enzymes: PEPCK, pyruvate kinase, transaminase, GGPHD, malic enzyme 
or glucose synthesis (Dunn and Hartsook, 1980).

Simultaneous experiments were performed to study amino-acid metabolism and hormonal modifications induced by obesity. Insulin is more active in lipogenesis than in proteinogenesis in Zucker rats which have been previously treated with alloxan (Chan et al, 1982; Stolz an Martin, 1982). According to these last authors hyperinsulinism is not necessary to induce obesity in the Zucker rat; moderate injections of insulin in streptozotocin-treated rats led to a larger increase of lipid deposition and a lower protein gain in the obese genotype. Similarly Sharghill et al (1984), using ob/ob mice, showed that muscular proteinogenesis is reduced in the obese genotype and that it is insensitive to insulin. The antiproteolytic effect of IGF-I disappeared in the Zucker rat compared with its normal counterpart (Jacob et al, 1992), which parallels the antiproteolytic effect of insulin. Different conclusions were drawn from experiments performed on gold-thioglucose-induced obesities in mice. In this case both proteinogenesis and proteolysis seemed to be reduced in muscles of obese animals (Monier et al, 1983; Augert et al, 1986).

Integrative interpretation of all these observations is not easy, since feed consumption of obese individuals is always larger than that of the normal, and, as a consequence, amino-acid intake is also higher. We cannot conclude whether hepatic transamination and gluconeogenesis, and the deviation of carbon from amino acid to lipogenesis is a consequence of the larger protein intake or a primary mechanism induced by obesity and its abnormal hormonal balance. However, it seems that both proteogenesis and proteolysis are modified by insulin (and IGF-1) resistance. However some discrepancies are to be noted between genetic and gold-thioglucoseinduced obesities and between in vivo and in vitro studies.
Nutritional consequences have been studied by some authors. Radcliffe and Webster (1978) found that the obese Zucker rat tended to increase its feed consumption as protein content increased up to $30 \%$ casein, instead of $15 \%$ for the normal rat. This could probably be a consequence of the reduced efficiency of amino-acid utilisation by the obese genotype, suggesting that systematic deamination of amino acids is one of the primary metabolic mechanism involved by obesity.

Tews and Harper (1982) observed that ob/ob mice are more sensitive to threonine deficiency than normal mice. A similar observation was made by Radcliffe (1977) using the Zucker rat and lysine deficiency. The obese rat was less sensitive to lysine deficiency ( $10 \%$ gluten) and also less sensitive to lysine excess $(10 \%$ gluten $+4 \%$ lysine $)$.

Again, interpretation of these observations is not easy since both genotypes did not ingest the same amounts of dietary amino acids. The obese genotypes may consume larger amounts of amino acids and, as a consequence, they are able to cover their requirements for essential amino acids. Excesses of other amino acids are then used for glyconeogenesis and lipogenesis.

\section{HUMAN OBESITIES}

There are many published papers on modifications of amino-acid metabolism induced by obesity in humans. However, 2 problems lead to difficulties of interpretation of these observations: 1) we are never sure that the obesities are of genetic origin; and 2) many experiments have been performed on adult individuals with constant protein pools as compared to growing animals. However interesting comparisons can be made. A recent review by Caballero (1987) summarized more than 70 papers published on this topic. 
As in obese rodents, some changes in plasma amino-acid concentrations are observed in human obesities (table IV). The more constant modification concerns BCAAs, which are found in larger amounts in obese human beings. Caballero et al (1988) found a lower tryptophan to large neutral amino-acid ratio in plasma from obese patients. They proposed that this ratio, which reflects a low concentration of tryptophan in plasma, may influence appetite via neuroendocrine processes involving the neuro-transmitter serotonin. Metabolic deviation by diminishing the tryptophan available for serotonin synthesis and its release in the brain, may induce an hyperphagic behaviour (appetite for carbohydrates) leading to obesity. Similar changes of the ratio between tryptophan and large neutral amino acids were observed by Chee et al (1981a) between lean and obese mice.

Several studies were undertaken in order to look at the metabolic and hormonal changes which may have been associated with obesity (table V). Felig et al (1974) showed that BCAA, aromatic amino acids (phenylalanine and tyrosine), threonine, alanine and sulphur amino acids are found in higher concentrations in the plasma of obese humans. These changes are thought to be the consequences of increased muscle proteolysis. Liver uptake of alanine and lactate are enhanced by 50 to $160 \%$ in obese human beings. Berger et al (1978) observed a negative correlation between insulin efficiency and plasma concentrations of BCAA. Diabetic humans exhibit larger concentrations than controls. On the contrary, insulinoma induced significantly lower BCAA concentrations in plasma. Forlani et al (1984) used the clamp methodology (insulin + glucose), to conclude that the decrease of plasma BCAA induced by insulin perfusion (Fukagawa et al, 1986) is much less pronounced in obese humans than in controls; these authors suggested that insulin resistance impairs glucose and

Table IV. Plasma concentration of amino acids in obese human beings.

\begin{tabular}{|c|c|}
\hline Reference & Observation \\
\hline Berger et al (1978) & $\begin{array}{l}\text { Increased BCAA } \\
\text { concentration }\end{array}$ \\
\hline Nair et al (1983) & $\begin{array}{l}\text { Increased leucine } \\
\text { concentration }\end{array}$ \\
\hline Schauder et al (1987) & $\begin{array}{l}\text { Increased BCAA } \\
\text { concentration }\end{array}$ \\
\hline Caballero et al (1988) & $\begin{array}{l}\text { Increased BCAA } \\
\text { concentration, lower } \\
\text { tryptophan/LNAA ratio }\end{array}$ \\
\hline $\begin{array}{l}\text { Jensen and Haymond } \\
\text { (1991) }\end{array}$ & $\begin{array}{l}\text { Increased BCAA } \\
\text { concentration }\end{array}$ \\
\hline
\end{tabular}

BCAA = branched-chain amino acids; LNAA = large neutral amino acids (valine, leucine, isoleucine, tyrosine phenylalanine and methionine).

Table V. Modifications of amino-acid metabolism associated to human obesities.

Reference

Felig et al (1974)

Berger et al (1978)

Forlani et al (1984)

Lower efficiency of insulin to reduce BCAA in plasma (clamp with insulin and glucose)

Schauder et al (1987) Plasma BCAA concentration increased due to enhanced proteolysis

Jensen and Haymond Increased proteolysis (1991) due to insulin resistance 
BCAA utilisation by muscle to the same extent. A recent study by Jensen and Haymond (1991) confirms that proteolysis is increased in moderate obesity. These authors distinguished upper-body obesity from lower-body obesity in women. Basal flux of leucine, measured by infusion of ${ }^{14} \mathrm{C}$ leucine was significantly higher in obese women, although no significant differences were found for plasma concentration of leucine in these cases of moderate obesity. Insulin reduced the leucine flux and $\alpha$ ketoisocaproate flux more efficiently in normal than in obese women. The upper-body obese seemed to be more resistant to insulin. Lastly these authors associated this higher resistance to insulin to a lower number of insulin receptors in muscles of upperbody obese women.

We have disregarded in this review many papers published on caloric restriction in obese humans and its consequences on nitrogen balance. All these studies were undertaken on obese humans without controls. Moreover, they are not easy to interpret since they involve energy metabolism and protein metabolism in conditions of negative energy balance.

From the published work discussed, we may conclude that some similarities can be found with monogenic obesities of rodents: elevated plasma levels of BCAA in the obese; increased muscle proteolysis due to insulin resistance; and probably reduced proteinogenesis and an enhanced use of amino acids for neoglucogenesis.

\section{FARM ANIMALS}

Different models of lean or obese animals have been developed for animal production purposes. In pigs and chickens, there are several comparisons either of lean genotypes to control genotypes, or lean to obese genotypes but rarely on obese to control genotypes. Moreover in the last 5 years sev- eral papers have been published on the consequences of hormone-induced leanness on amino-acid metabolism in pigs. We shall consider studies performed on this latter species first and then those published on chickens.

As regards rodents, pig obesity induces a lower lean mass (Cote and Wangsness, 1978). Conversely, selection for leanness or hormone-treatment (growth hormone or beta-agonist) increases lean body mass and muscle proportion.

The protein requirements of a lean and a control line of pigs have already been investigated (Davey and Morgan, 1969; Davey, 1976; Bereskin and Davey, 1978). These authors all confirmed that lean genotypes require diets containing a higher proportion of protein. Even if growth rate or lean body mass of the control line was increased by a high-protein diet, this increase was always more pronounced in lean pigs. As shown in table VI feed consumptions of the genotypes were not very different. However distributions between lipid and protein in the carcass were always very different between genotypes. From this study it seems that in the lean genotype the protein utilisation is similar or superior to that of the obese genotype. Similarly, muscle gain was more significantly increased by the high-protein diet or by supplementation of the control diet by lysine and methionine in lean pigs than in controls (Bereskin and Davey, 1978). There are several published papers which are less easy to interpret as the pigs were energyrestricted.

Several hormonal treatments have been developed recently to reduce adiposity in pigs. Two kinds of hormones or analogues were used: beta-agonist or growth hormone obtained by genetic engineering, porcine samatotropin (p-ST). Ractopamine is a betaagonist, which can reduce lipid gain and increase protein gain. Mitchell et al (1990) compared 2 protein levels combined with or without supplementation by ractopamine. 
Table VI. Effect of genotype and dietary protein on growth and body composition of growing pigs (from Davey, 1976).

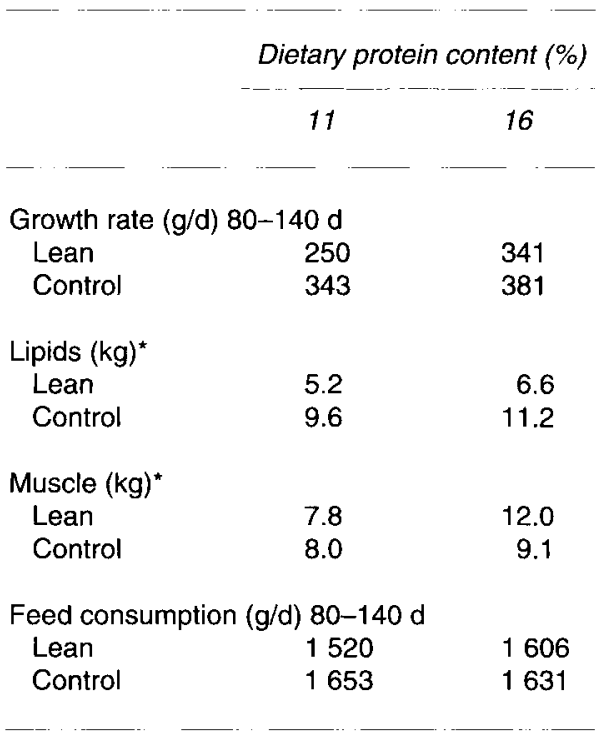

* Means of measurements at 3 ages $(140,200$, $260 \mathrm{~d})$.

The beta-agonist effect on feed conversion and protein gain was more pronounced in pigs selected on the high-protein diet than in those selected on a low-protein diet.

Many more papers have been published for growth hormone treatments $(p-S T)$. PST treatment increases growth rate, lean body mass gain; it reduces feed intake and lipid gain and improves feed conversion. Several recent experiments have studied interactions between this induced leanness and the utilisation of dietary protein. Caperna et al (1990) observed that growth rate is increased by dietary protein content but this effect was more pronounced when piglets were treated with p-ST. Maximum growth rate was reached using approximately $19 \%$ protein in diet for controls rather than $23 \%$ for treated pigs. Feed conversion was better in pST-treated animals than in controls. Pro- tein gain was always superior in treated pigs whatever the dietary protein concentration, but the beneficial effect of increasing the protein level on lean body mass gain was more pronounced in treated animal. When protein gain is plotted against protein intake, as shown in figure 1 , the slopes of regression lines were very different suggesting a more efficient utilisation of dietary amino acids by the lean pigs. Lastly, as protein concentration increased in the diet, fat deposition was reduced in both groups but this effect was more pronounced in p-ST-treated pigs.

Campbell et al (1991) found that maximum protein gain is higher in $\mathrm{p}$-ST-treated pigs. Protein gain was improved by increasing protein intake. Lastly $p$-ST-treated pigs required more protein to reach their maximum potential of protein deposition.

Similar conclusions can be drawn from the studies of Smith and Kasson (1991) and Quiniou et al (1993). Somatotropin treatment enhanced growth rate and muscle proportion, and decreased fat thickness and feed consumption. This effect became more significant as dietary protein content was increased from $14-18$ and $20 \%$.

Several recent observations have been made regarding the metabolic effect of $\mathrm{p}-\mathrm{ST}$. Firstly $\mathrm{p}$-ST reduced the plasma concentration of BCAA in pigs (Goodband et al,

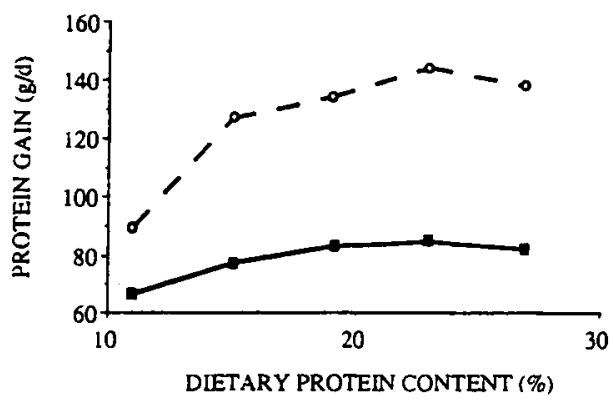

Fig 1. Regression between protein gain and protein intake in lean ( $p-S T$ treated) $(O)$ and control (口) piglets. Calculated from Caperna et al (1990). 
1993), which is in accordance with the positive correlation between obesity and BCAA concentration in plasma found in rodents and humans. p-ST treatment also decreased uremia and increased plasma glucose (Goodband et al, 1993) whatever the dietary lysine concentration, and the adipose tissue of p-ST-treated pigs became resistant to insulin. Consequently plasma insulin and glucose were increased.

Dietary protein utilisation was further investigated by Noblet et al (1992) and the linear regressions between protein gain and protein intake were significantly different between control and treated groups (fig 2). The efficiency of protein retention was $41 \%$ in the p-ST-treated group and 30\% in controls. Moreover, at any protein intake, protein retention of lean pigs was superior to that of control pigs. This reflects (as does uremia) a more efficient utilisation of dietary amino acids and, as a consequence, lower nitrogen losses from lean pigs (Quiniou et al, 1993). Whatever the dietary protein content (15.7 or $18.6 \%$ ), p-ST reduced nitrogen excretion in both absolute and relative values (table VII). In this experiment p-ST increased aminoacid retention (in castrated males between 50 and $100 \mathrm{~kg}$ ) by $35 \%$ and decreased nitrogen excretion by $25 \%$. Similar observations were made by Sève et al (1993). Furthermore, these latter authors studied the effects of the hormone on proteinogenesis and pro-

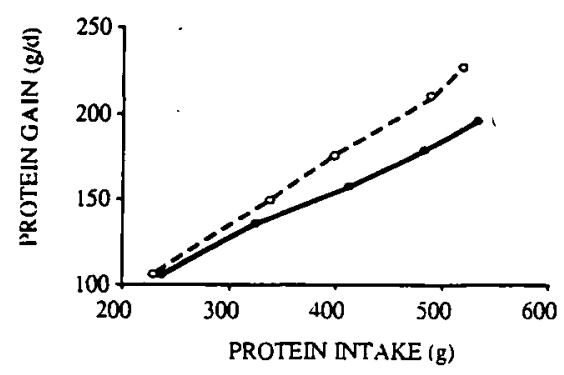

Fig 2. Regression lines between protein gain and protein intake in control $(\bullet)$ and $\mathrm{p}$-ST treated barrows (O) (from Noblet et al, 1992). Treated: $y=$ $2.1+0.41 x$, control: $y=5.9+0.30 x$. teolysis using ${ }^{13} \mathrm{C}$-valine injected into the jugular vein. The fractional synthesis rate of muscle proteins was enhanced by $\mathrm{p}-\mathrm{ST}$; the increase was higher for the high protein level than for the low protein diet $(+24 \mathrm{vs}$ $+16 \%$ ). Enhancement of the fractional synthesis rate of liver protein was also enhanced by $\mathrm{p}-\mathrm{ST}$, but to a lower extent $(+$ $16 \%)$. The increase in protein gain was mainly due to increased proteogenesis, as protein degradation did not seem to be affected. As shown in many other studies, plasma glucose concentration was higher in lean pigs than in controls. $p$-ST increased insulin concentration in the plasma of pigs just after valine injection. Circulating IGF-I was found at higher concentration in treated animals whatever the protein level.

Leanness induced in pigs either by genetic means or by hormonal treatment increases lean body mass, muscle proportion and protein requirement expressed as protein concentration in the diet. However, it also increases protein retention at a given protein intake, at least below or at the requirement level. Lean pigs use dietary amino acids more efficiently. This seems to be due to enhanced proteogenesis. As a consequence, nitrogen excretion (and ure$\mathrm{mia}$ ) are lowered in lean pigs (Sève et al, 1993).

Lean lines of chickens have been selected since 1980 , either by direct selection using abdominal fat as the selection trait or by indirect selection using feed efficiency or plasma VLDL (Leclercq and Whitehead, 1988).

Comparisons between lean, control and obese chickens resulted in many similar conclusions. Muscle proportions were always significantly higher in the lean genotype than in the control or in the obese (Ricard and Touraille, 1988). Partition between fat gain and protein gain was significaltly different, even at similar feed energy or protein intakes (McLeod and Geraert, 1988). As shown in table VIII, the ratio 
between protein gain and protein intake was always superior in the lean genotype, suggesting a more efficient use of dietary amino acid. Moreover, it was observed that the French lean line exhibits a higher feather proportion that the fat line (Leclercq and Guy, 1991; Geraert et al, 1993; Leclercq et al, 1993) which could be interpreted as a metabolic trend towards protein synthesis. As a consequence, nitrogen excretion is reduced in the lean genotype, whatever the dietary protein content (Geraert et al, 1990).

The comparative sensitivity of fat and lean chickens to protein concentration in the diet is controversial. Leclercq (1983) observed that the lean chickens were more sensitive to protein deficiency when dietary protein content was reduced by replacing soybean meal by maize; this resulted in modifying the amino acid (principally essential amino acid) composition. This was not observed when the amino-acid composition was kept constant by diluting a well-balanced protein with a protein-free diet (Leclercq and Guy, 1991) (fig 3). These results were confirmed by recent experiments on comparative sensitivity to sulphur amino acid, lysine or arginine deficiency, which were much more pronounced in lean chickens (Leclercq et al, 1993; Leclercq et al, 1994). However, when weight gain was plotted against protein intake or amino-acid intake, both genotypes were on the same linear or curvilinear regression lines. This suggests that the effect of protein imbalance is partly due to a specific effect on appetite in the lean genotype which would be more sensitive to essential amino-acid

Table VII. Effect of $\mathrm{p}-\mathrm{ST}(3 \mathrm{mg} / \mathrm{d})$ and dietary protein on nitrogen retention and nitrogen excretion in pigs (from Quiniou et al, 1993).

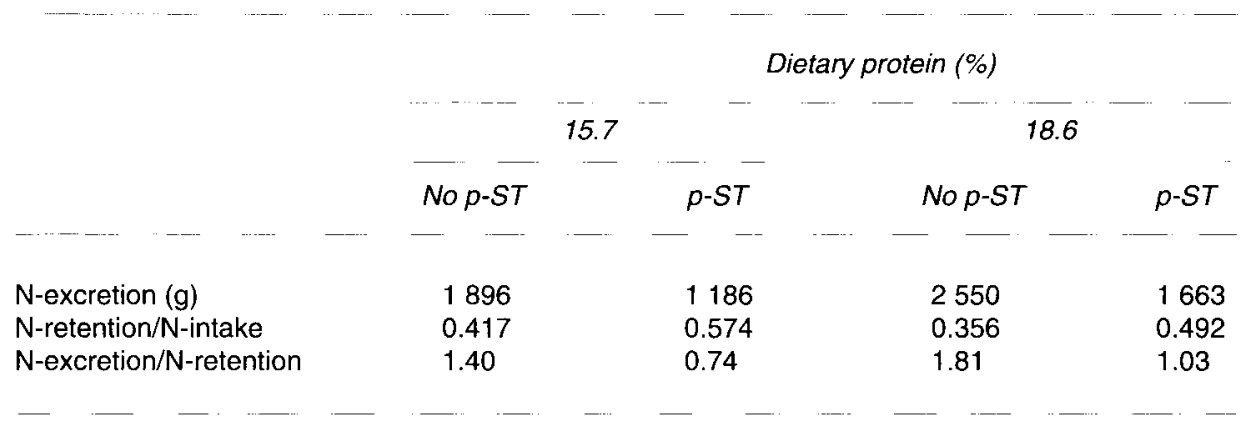

Table VIII. Protein efficiency (protein gain to protein intake ratio) in genetically lean or obese chickens.

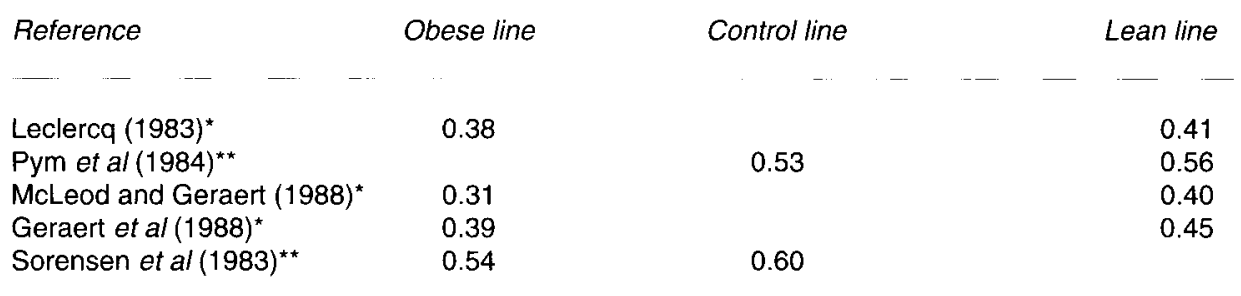

* Body proteins (without feathers); "* total proteins (including feathers). 

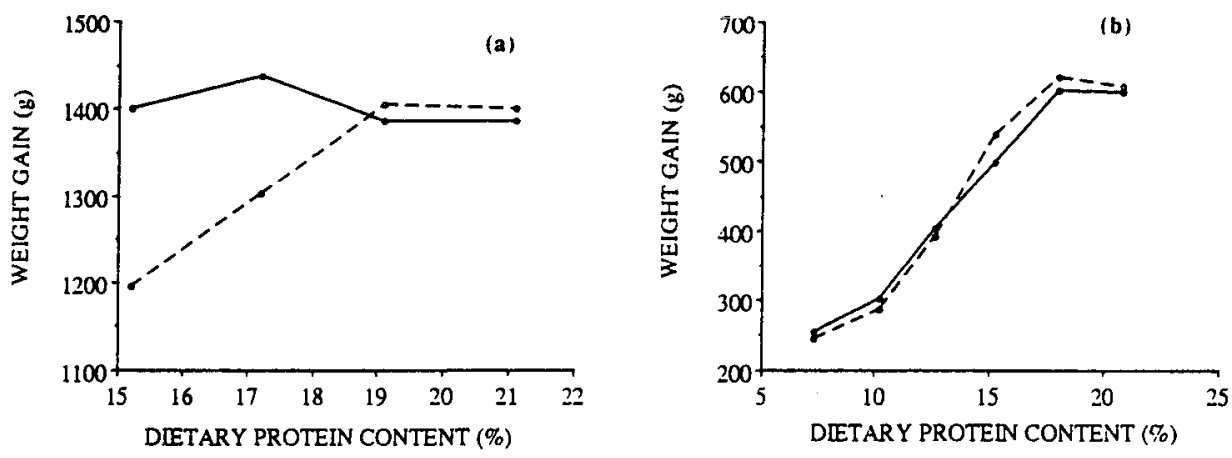

Fig 3. Comparative sensitivity of genetically lean $(O)$ and obese $(\bullet)$ chickens to dietary protein: $a=$ variable amino-acid balance; $b=$ constant amino-acid balance .

imbalance. Different behaviour of fat and lean lines were previously observed for protein. When they had a free choice between a high- $(26.9 \%$ crude protein) and a lowprotein diet $(14.5 \% \mathrm{CP})$, lean chickens ate a significantly larger amount of the high-protein ration than the fat chickens.

Regressions between protein gain and protein intake have been measured several times (Leclercq, 1983; Geraert et al, 1990; Leclercq and Guy, 1991). The slope of the regression line p-ST-treated pigs was higher in the lean genotype and, at any given protein intake, protein retention was higher in the lean chickens. Similarly when protein gain was plotted against methionine, lysine or arginine intake (at least before the requirement is reached) at any given aminoacid intake protein gain was higher in the lean line. This suggests a more efficient metabolic utilisation of these amino acids in the lean line than the fat line.

The mechanisms involved in these metabolic differences are not well understood. Very consistent and significant differences were found in plasma amino acids at the fed state; these are summarized in figure 4. Fat chickens exhibited higher concentrations of sulphur amino acids, BCAA and lower concentration of several non- essential amino acids (alanine, glutamic acid, glutamine) and histidine (which is catabolised into glutamic acid) (Pesti et al, 1994). Larger concentrations of BCAA in fat chickens can be compared with those in obese rodents or humans. Lower concentrations of non-essential amino acids may be similar to observations in rodent or human obesity, which induce enhanced utilisation of carbon from amino acids to neoglucogenesis or lipogenesis. The last hypothesis was investigated by Geraert et al (1986) who observed in vivo that more carbon from alanine was incorporated into fatty acids in the fat chickens.

\section{CONCLUSIONS}

Several similarities can be drawn from different models of fatness or leanness. Firstly protein gain or lean body mass is impaired in the obese genotype. This seems due in most cases to changes of proteogenesis rather than modification of proteolysis, even though proteolysis seems to be increased in mammal obesities, as a consequence of insulin resistance. Indeed several authors suggest that insulin and IGF-I exert a strong effect on proteolysis by decreasing it. The 


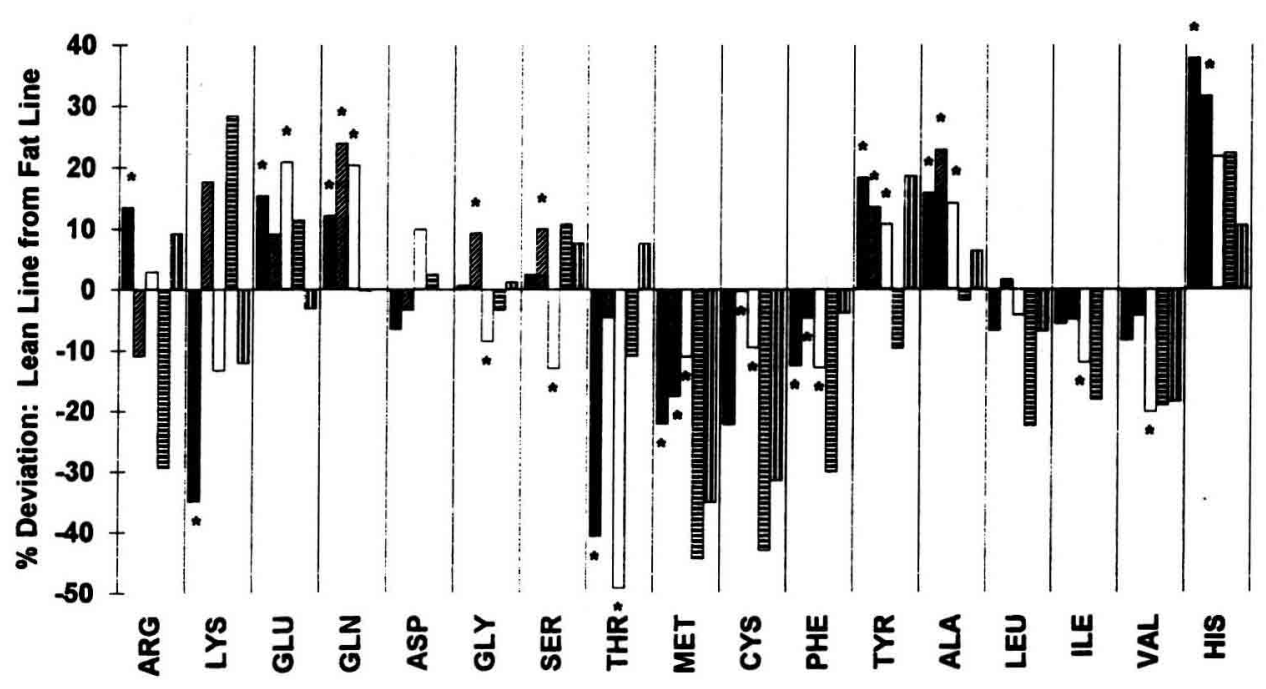

Fig 4. Amino-acid concentration in plasma of obese and lean chickens (\% deviation lean from fat line) (from Pesti et al, 1994); results from 5 experiments.

efficiency of insulin action seems to be impaired in most obesities leading to enhanced amino-acid (mainly BCAA) release by muscles. Further experiments are needed on different models of obesity to better understand the relative role of different tissues or organs (liver, muscles) in amino-acid turnover according to obesities.

What is sure is that efficiency of protein and amino-acid metabolism is clearly different between obese and lean genotypes. Obese animals are less able to synthesize their protein from dietary amino acids. This conclusion is well-established in farm animals (pigs and chickens). It is less clear in rodent obesities since feed consumption, and, as a consequence, protein consumption is much higher in the obese genotype. However work by Radcliffe and Webster (1978) suggests that, as in farm animals, obese rats require more dietary protein to synthesize body protein, even at low concentrations of dietary protein. If this conclusion is confirmed, it could be hypothesized that deviation of amino-acid metabolism, probably in the liver, is one of the first direct consequences of the primary cause of obesity, instead of a consequence of increased feed consumption.

We cannot exclude specific differences between obese and lean animals for sensitivities of appetite to amino-acid balance or dietary protein concentration as suggested by observations in Zucker rats (Chee et al, 1981b; Castonguay et al, 1982) or fat chickens.

Nevertheless the number of papers published on the relationship between aminoacid metabolism and obesity are scarce. Further research would be necessary to know the exact mechanisms involved in the deviation of amino acids from proteogenesis towards lipogenesis. Moreover we do not know if all amino acids are affected to the same extent, if genetic changes are located at the level of amino-acid transport or amino acid.

This could have practical consequences on the amino-acid requirements of obese or lean genotypes. 


\section{REFERENCES}

Augert G, Monier S, Lemarchand-Brustel Y (1986) Effect of exercise on protein turn-over in muscles of lean and obese mice. Diabetologica 29, 248-253

Bereskin B, Davey RJ (1978) Genetic, sex and diet effects on pig carcass trait. J Anim Sci 1, 581-1591

Berger $\mathrm{M}$, Zimmerman-Telschow $\mathrm{H}$, Berchtold $\mathrm{P}$ et al (1978) Blood amino-acid levels in patients with insulin excess (functioning insulinoma) and insulin deficiency. Metabolism 27, 793-799

Caballero B (1987) Insulin resistance and amino-acid metabolism in obesity. Ann NY Acad Sci 499, 8493

Caballero B, Finer N, Wurtman RJ (1988) Plasma aminoacid and insulin levels in obesity: response to carbohydrate intake and tryptophan supplement. Metabolism 37, 672-676

Campbell R, Johnson RJ, Taverner MR, King RH (1991) Interrelationships between exogenous porcine somatotropin (PST) administration, dietary protein and energy intake on protein deposition capacity and energy metabolism of pigs. J Anim Sci 69, 1522-1531

Caperna TJ, Teele NC, Komarek DR et al (1990) Influence of dietary protein and recombinant porcine somatotropin administration in young pigs; growth, body composition and hormone status. J Anim SCl $68,4243-4252$

Castonguay TW, Hartman WJ, Fritzpatrick EA, Stern JS (1982) Dietary self selection and the Zucker rat. J Nutr 112, 796-800

Chan CP, Koon LJ, Stern JS (1982) Effect of insulin on fat and protein deposition in diabetic and lean obese rats. Am J Physiol 242, E19-E24

Chan CP, Hanser RJ, Stern JS (1985) Protein turnover in insulin-treated, alloxan-diabetic, lean and obese Zucker rats. J Nutr 115, 959-969

Chee DM, Romsos DR, Bergen WG, Leveille GA (1981a) Protein intake regulation and nitrogen retention in young obese and lean mice. J Nutr 111, 58-67

Chee KM, Romsos DR, Bergen WG (1981b) Effect of dietary fat on protein intake regulation in young obese and lean mice. J Nutr 111, 668-677

Chu SH, Samonds KW, Seronde J, Hegsted DM (1978) Protein utilization and lysine metabolism in obese and non-obese growing rats. J Nutr 108, 567-577

Cleary MP, Vasselii JR (1981) Reduced organ growth when hyperphagia is prevented in genetically obese (fa/fa) Zucker rats. Proc Soc exp Biol Med 167, 616623

Cote PL, Wangsness PJ (1978) Rate, composition and efficiency of growth in lean and obese pigs. $J$ Anim Sci $47,441-447$
Davey RJ (1976) Growth and carcass characteristics of high- and low-fat swine fed diets varying in protein and lysine content. J Anim Sci 43, 598-605

Davey RJ, Morgan DP (1969) Protein effect on growth and carcass composition of swine selected for high and low fatness. J Anim Sci 28, 831-836

Dumas P, Autissier N, Loireau A, Michel R (1982) Effect of $3,5,-E$-triiodothyroacetic acid on protein metabolism of genetically obese or non-obese Zucker rats. CR Séances Soc Biol 176, 178-183

Dunn MA, Hartsook EW (1980) Comparative aminoacid protein metabolism in obese and non-obese Zucker rats. J Nutr 110, 1865-1879

Dunn MA, Houtz SK, Hartsook EW (1982) Effects of fasting on muscle protein turnover, the composition of weight loss and energy balance of obese and nonobese Zucker rats. J Nutr 112, 1862-1875

Durschlag RP, Layman DK (1983) Skeletal muscle growth in lean and obese Zucker rats. Growth 47, 282-291

Felig P, Wahren J, Hendler R, Brudin T (1974) Splanchnic glucose and amino-acid metabolism in obesity. $J$ Clin Invest 53, 582-590

Forlani G, Vannini P, Marchesini G, Zoli M, Ciavarella A, Pisi E (1984) Insulin-dependent metabolism of branched-chain amino acids in obesity. Metabolism $33,147-150$

Fukagawa NK, Minaker KL, Young VR, Rowe JW (1986) Insulin-dose-dependent reductions in plasma amino acids in man. Am J Physiol 250, E13-E17

Geraert PA, Guillaumin S, Leclercq B, Larbier M (1986) Utilisation des acides aminés à des fins énergétiques chez les poulets génétiquement maigres ou gras. In: Proc VII Eur Poult Conf (M Larbier, ed), Paris, France

Geraert PA, McLeod MG, Leclercq B (1988) Energy metabolism in genetically fat and lean chickens: dietand cold-induced thermogenesis. J Nutr 118, 12321239

Geraert PA, McLeod MG, Larbier M, Leclercq B (1990) Nitrogen metabolism in genetically fat and lean chickens. Poult Sci69, 1911-1921

Geraert PA, Guillaumin S, Leclercq B (1993) Are genetically lean broilers more resistant to hot climate? $\mathrm{Br}$ Poult Sci 34, 643-653

Goodband RD, Nelssen JL, Hines RH (1993) Interrelationships between porcine somatotropin and dietary lysine on growth performance and carcass characteristics of finishing swine. J Anim Sci 71 , 663-672

Jacob RJ, Sherwin RS, Greenawalt K, Shulman GI (1992) Simultaneous insulin like growth factor I and insulin resistance in obese Zucker rats. Diabetes 41 691-697 
Jensen MD, Haymond MW (1991) Protein metabolism in obesity: effect of fat distribution and hyperinsulinemia on leucine turnover. Amer J Clin Nutr 53, 172-176

Kleinknecht C, Gros F, Jean G, Broyer M (1980) Growth and free amino acids in uremic hyperphagic rats. Amer J Clin Nutr 33, 1690-1695

Leclercq B (1983) The influence of dietary protein content on the performances of genetically lean or fat growing chickens. Br Poult Sci 24, 581-587

Leclercq B (1988) Genetic selection of meat-type chickens for low or high abdominal fat. In: Leanness in Domestic Birds: Genetic, Metabolic and Hormonal Aspects. Butterworths, London, UK

Leclercq B, Guy G (1991) Further investigations on protein requirement of genetically lean and fat chickens. Br Poult Sci 32, 785-794

Leclercq B, Chagneau AM, Cochard T, Hamzaoui S, Larbier M (1993) Comparative utilisation of sulphur amino acids by genetically lean or fat chickens. $\mathrm{Br}$ Poult Sci 34, 383-391

Leclercq B, Chagneau AM, Cochard T, Khoury J (1994) Comparative responses of genetically lean and fat chickens to lysine, arginine and non-essential amino acid supply. 1 Growth performance and body composition. Br Poult Sci 35, (in press)

Lemarchand $Y$, Freychet $P$ (1980) Effect of insulin on amino-acid transport in isolated soleus muscles of lean and obese mice. Diabetologia 19, 294 (abstr)

Lin PY, Romsos DR, Leveille GA (1977) Food intake, body weight gain and body composition of the young obese (ob/ob) mouse. J Nutr 107, 1715-1723

Lobley GE, Webster AJF, Reeds PJ (1978) Protein syntheis in lean and obese Zucker rats. Proc Nutr Soc $37,20 \mathrm{~A}$

McLeod MG, Geraert PA (1988) Energy metabolism in genetically fat and lean birds and mamals. In: Leanness in Domestic Birds: Genetic, Metabolic and Hormonal Aspects (Leclercq B, Whitehead CC, eds) Butterworths, London, UK, 109-120

Mitchell AD, Solomon MB, Steele NC (1990) Response of low and high protein select lines of pigs to the feeding of the beta-adrenergic agonist Ractopamine (Phenethanol amine). J Anim Sci68, 3226-3232

Monier S, Le Cam A, Lemarchand-Brustel Y (1983) Insulin and insulin-like growth factor. I. Effect on protein synthesis in isolated muscles from lean and gold-thioglucose obese mice. Diabetes 32, 392397

Nair KS, Garrow JS, Ford C, Mahler RF, Halliday D (1983) Effect of poor diabetic control and obesity on whole body protein metabolism in man. Diabetologia $25,400-403$

Noblet J, Dubois S, Herpin P, Sève B (1992) Influence de I'utilisation de la somatotropine porcine sur l'utilisa- tion de l'énergie et des protéines chez le porc. $J$ Rech Porc 24, 237-248

Pesti GM, Leclercq B, Chagneau AM, Cochard T (1994) Comparative response of genetically lean and fat chickens to lysine, arginine and non-essential aminoacid supply. 2. Plasma amino-acid responses. $B r$ Poult Sci (in press)

Pym RA, Nicholls PJ, Thomson E, Choice A, Farrell DJ (1984) Energy and nitrogen metabolism of broilers selected over ten generations for increased growth rate, food intake and conversion of food to gain. $\mathrm{Br}$ Poult Sci 25, 529-539

Quiniou N, Noblet J, Dourmad JY (1993) Effets de l'administration de somatotropine porcine et d'une réduction du taux protéique du régime sur les rejets d'azote et de phosphore chez le porc. J Rech Porc 25, 287 294

Radcliffe JD (1977) The effect of increasing the dietary lysine concentration on food intake and growth in the Zucker rat. Proc Nutr Soc 36, 139A

Radcliffe JD, Webster AJ (1976) Regulation of food intake during growth of fatty and lean female Zucker rats given diets of different protein content. Br J Nutr $36,457-469$

Radcliffe JD, Webster AJF (1978) Sex, body composition and regulation of food intake during growth in the Zucker rat. Br J Nutr 39, 483-492

Ricard FH, Touraille C (1988) Selection for leanness and carcass quality. In: Leanness in Domestic birds: Genetic, Metabolic and Hormonal aspects (Leclerca B, Whitehead CC, eds) Butterworths, London, UK, 377-386

Schauder P, Zavelberg D, Klanger K, Herbertz L (1987) Sex specific differences in plasma branched chain keot acids levels in obesity. Am J Clin Nutr 46, 58-60

Serra F, Gianotti M, Palou A, Pons A (1991) Dietary obesity shows adaptations of amino-acid metabolism on enzyme activities to save amino nitrogen. Bioch Intern 24, 769-776

Sève B, Ballèvre O, Ganier P, Noblet J, Prugnaud J Obled C (1993) Recombinant porcine somatotropin and dietary protein enhance protein synthesis in growing pigs. J Nutr $123,529-540$

Sharghill NS, Ohshima K, Bray GA, Chan TM (1984) Muscle protein turnover in the perfused hindquarters of lean and genetically obese-diabetic (ob/ob) mice. Diabetes 33, 1160-1164

Smith VG, Kasson CW (1991) The interrelationship between crude protein and exogenous porcine somatotropin on growth, feed and carcass measurements of pigs. J Anim Sci 69, 571-577

Sorensen P, Chwalibog A, Eggum BO (1993) Protein and energy metabolism in two lines chickens selected for growth on high or low protein diets. Br Poult Sci $24,237-250$ 
Stolz DJ, Martin RJ (1982) Role of insulin in food intake, weight gain and lipid deposition in the growing Zucker obese rat. J Nutr 112, 997-1002

Tews JK, Harper AE (1982) Food intake, growth and tissue amino-acid concentrations in lean and obese (ob/ob) mice fed a threonine-imbalanced diet. J Nutr 112, 1673-1681

Webster AJ, Lobley G, Reeds PJ, Pullar JD (1978) Protein mass, protein synthesis and heat loss in the Zucker rat. Proc Nutr Soc 37, 21A
Whitehead CC (1988) Selection for leanness in broilers using plasma lipoprotein concentration as selection criterion. In: Leanness in Domestic Birds: Genetic, Metabolic and Hormonal Aspects (B Leclercq, CC Whitehead, eds), Butterworths, London, UK, 41-57

Yamini S, Staple RC, Hansen CT, Szepesi B (1991) Effect of dietary carbohydrate on liver and kidney enzyme activities and plasma amino acids in the LA/N-cp rats. Int J Obes 15, 189-203 